$1-1-1958$

\title{
Liquid manure conservation and use
}

\author{
A. D. Longhouse \\ O. J. Burger \\ H. O. Henderson
}

Follow this and additional works at: https://researchrepository.wvu.edu/ wv_agricultural_and_forestry_experiment_station_bulletins

\section{Digital Commons Citation}

Longhouse, A. D.; Burger, O. J.; and Henderson, H. O., "Liquid manure conservation and use" (1958). West Virginia Agricultural and Forestry Experiment Station Bulletins. 425.

https://researchrepository.wvu.edu/wv_agricultural_and_forestry_experiment_station_bulletins/403 @ WVU. It has been accepted for inclusion in West Virginia Agricultural and Forestry Experiment Station Bulletins by an authorized administrator of The Research Repository @WVU. For more information, please contact ian.harmon@mail.wvu.edu. 

$\therefore$ (A) $\ldots$

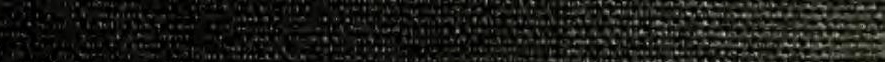

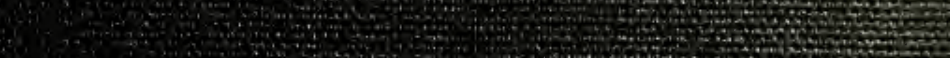

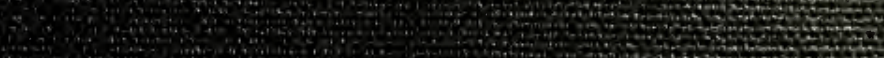

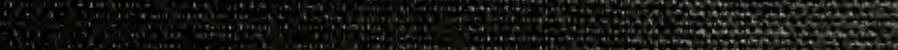
$\therefore$, Hin

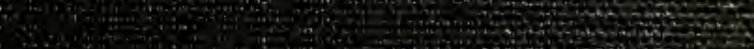
$\therefore$ (1)

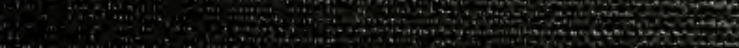

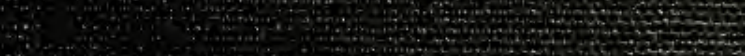

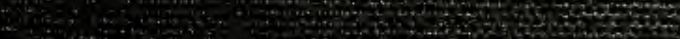

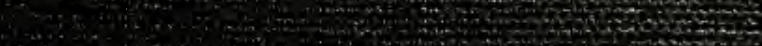

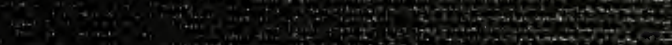
(2) the 30 ,

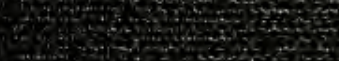

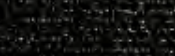
Q. 2015

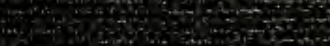

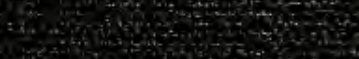

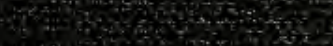

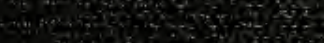

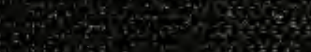
-3) 40 
Digitized by the Internet Archive in 2010 with funding from

Lyrasis Members and Sloan Foundation 


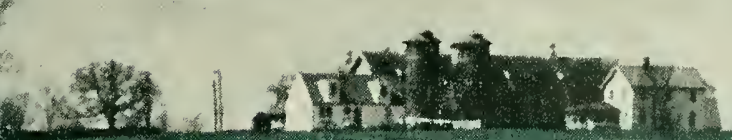
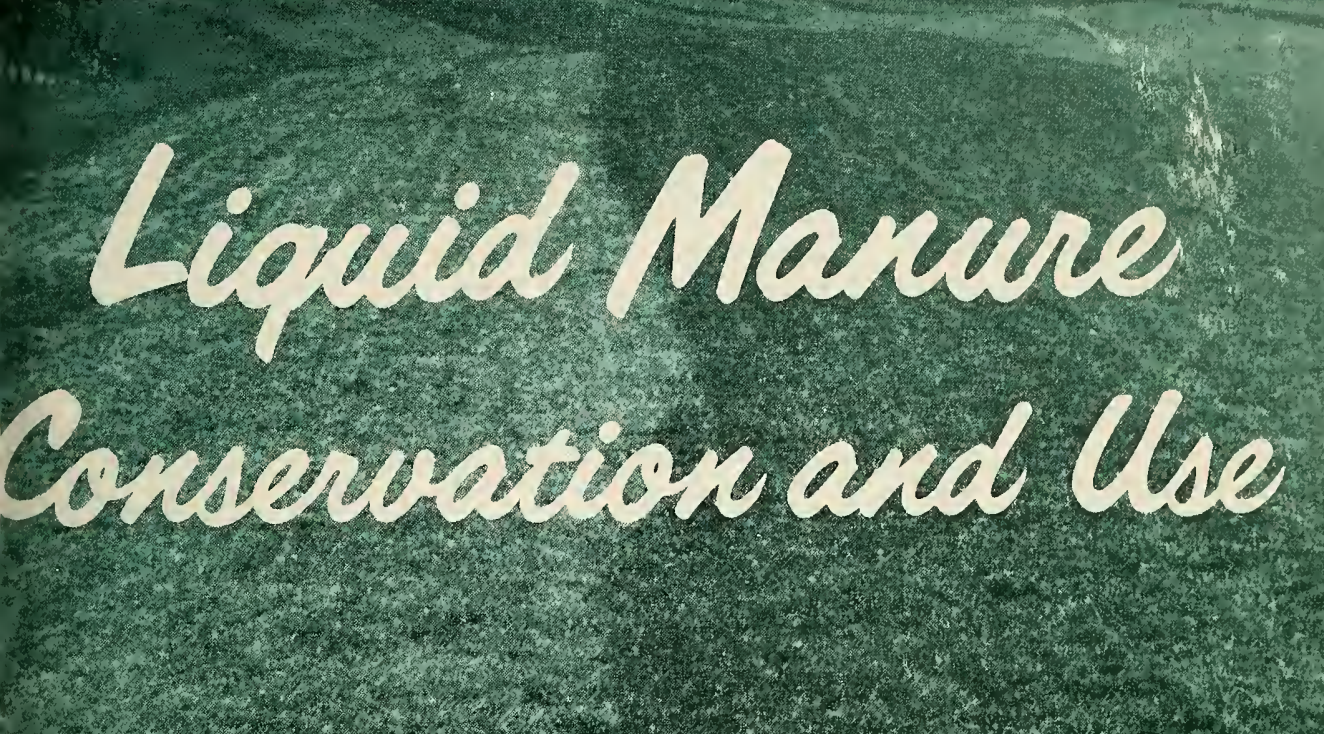

(1)

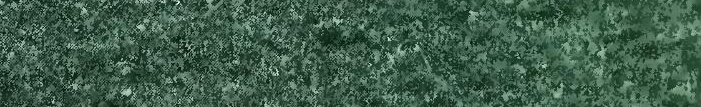

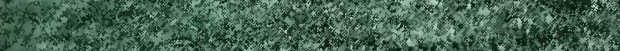

1.2.

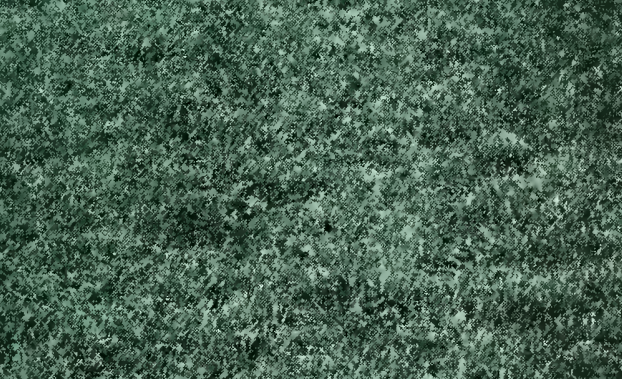
H. W (

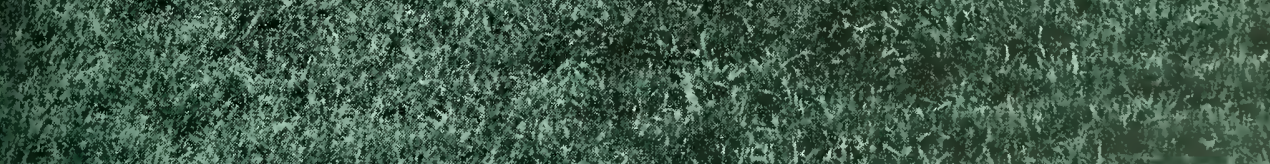

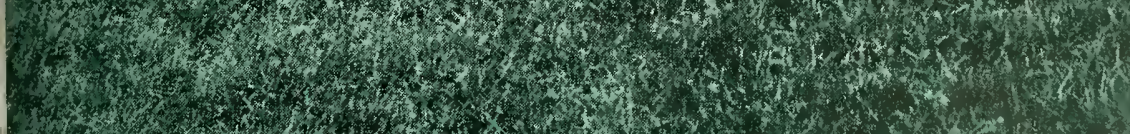

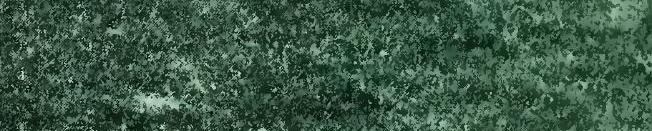

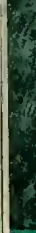

(-

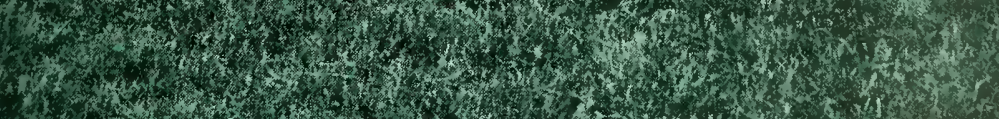

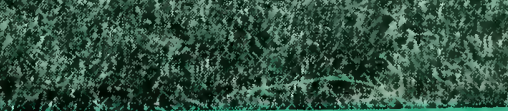

\section{West Virginia University} Agricultural Experiment Station

Bulletin 425 November 1958 


\title{
THE AUTHORS
}

A. D. Longhouse is Professor and Head of Agricultural Fngineering in the College of Agriculture, Forestry, and Home Economics, and Agricultural Engineer in the Agricultural Experiment Station. O. J. Burger was formerly Professor of Agronomy and Agronomist. H. O. Henderson is Professor of Dairy Husbandry and Dairy Husbandman in the Agricultural Experiment Station.

\section{ACKNOWLEDGMENT}

The authors wish to express their appreciation to James Travis Reid, ${ }^{1}$ who conducted most of the field experiments, and to Dr. G. G. Pohlman," for his helpful comments and suggestions.

${ }^{1}$ Formerly instructor in Agricultural Engineering.

"Head, Department of Agronomy and Genetics, and Agronomist.

\section{COVER PHOTOGRAPH}

The dark green color on the area on the right is the result of applications of liquid manure. The area on the left is untreated.

\author{
WEST VIRGINIA UNIVERSITY \\ Agricultural Experiment Station \\ College of Agriculture, Forestry, and Home Economics \\ Roy M. KotTMan, Director \\ MORGANTOWN
}




\section{Liquid Manure Conservation and Use}

A. D. LONGHOUSE, O. J. BURGER, and H. O. HENDERSON

\section{Introduction}

PPROXIMATELY one-half of the nitrogen and two-thirds of the potassium excreted by cattle are excreted as urine. Together, these constitute about one-half of the value of manure.

Many European and Asiatic farmers make a regular practice of collecting and distributing the liquid portion of manure. Common practice in America is to absorb all or part of the liquid in bedding. The liquid not absorbed is usually lost in drainage.

The present study was made to find practical ways of collecting, storing, and applying the liquid portion of manure not absorbed by bedding and to determine its effect on forage production.

\section{Experimental}

Studies on liquid manure were started at the Dairy Farm of the West Virginia University Agricultural Experiment Station in 1951. One section of the dairy barn housing 70 cows was used for the study.

The cattle were bedded in the normal method using straw, sawdust, or wood shavings to absorb most of the liquid. Liquid not absorbed was allowed to run down the gutter and into a 2,000-gallon concrete storage tank located at the lower side of the barn. On the assumption that the average cow voids 30 pounds of urine per day this tank would hold all the urine produced by the 70 head of cows in about 12 days.

A field that had been seeded to alfalfa, ladino clover and orchard grass in March 1949 was selected for demonstration and experimental plots. At the time the test was started the stand was primarily orchard grass. The area selected for demonstration work consisted of 5.8 acres: 2.84 acres were treated with liquid manure and 2.96 acres were retained as a check.

Collection of the liquid manure was started in October 1951. The manure was collected and applied at rates as shown in Table 1. Before application, samples of the liquid were taken to the laboratory and analyzed for nitrogen $(\mathrm{N})$ and potash $\left(\mathrm{K}_{2} \mathrm{O}\right)$. The results of these analyses are given in Table 1. 
Table 1. Amount of Liquid Manure Applied to the Field Demonstration Area, 1951 ANd 1952

\begin{tabular}{|c|c|c|c|c|c|}
\hline \multirow[t]{2}{*}{ Date Applied } & \multirow{2}{*}{$\begin{array}{c}\text { LIQUID } \\
L b s . / A c r C\end{array}$} & \multicolumn{2}{|c|}{ Nitrogen (N) } & \multicolumn{2}{|c|}{ Potash $\left(K_{2} \mathrm{O}\right)$} \\
\hline & & Per Cent & Lbs./Acre & Per Cent & Lbs./Acre \\
\hline November $2,1951 \ldots$ & 3298 & 0.101 & 3.33 & $0.1+1$ & 4.65 \\
\hline November $9 \quad \ldots . . . . . . .$. & 2426 & 0.065 & 1.58 & 0.071 & 1.72 \\
\hline November $16 \quad \ldots \ldots \ldots$ & 4912 & 0.156 & 7.66 & 0.137 & 6.73 \\
\hline November $26 \ldots \ldots . . . . .$. & 3503 & 0.169 & 5.92 & 0.288 & 10.09 \\
\hline November Total & 14139 & & 18.49 & & 23.19 \\
\hline December $7 \quad \ldots \ldots . . . .$. & 2334 & 0.166 & 3.88 & 0.235 & 5.48 \\
\hline December $28 \quad \ldots \ldots . . . .$. & 4424 & 0.160 & 7.08 & 0.165 & 7.30 \\
\hline December Total ... & 6758 & & 10.96 & & 12.78 \\
\hline January $18,1952 \ldots$ & 4753 & 0.296 & 14.07 & 0.457 & 21.72 \\
\hline January Total ... & 4753 & & 14.07 & & 21.72 \\
\hline February $6 \quad \ldots \ldots \ldots \ldots$ & 5134 & 0.164 & 8.42 & 0.224 & 11.50 \\
\hline February $27 \ldots \ldots \ldots$ & 1850 & 0.171 & 3.16 & 0.237 & 4.38 \\
\hline February Total ......... & 6984 & & 11.58 & & 15.88 \\
\hline TOTAL ........ & 32634 & 0.169 & 55.10 & 0.225 & 73.57 \\
\hline
\end{tabular}

Over the period from November 2 to February 27, 32,634 pounds of liquid manure were applied per acre. This contained 55.1 pounds of nitrogen and 73.57 pounds of potash by analysis.

Earlier growth was noted in March on the treated area. Both darker green color and greater growth continued to the time the material was cut for silage on May 22, 1952. The grass was mowed, windrowed, allowed to wilt and then picked up with a field forage harvester. Each load was weighed and a sample taken to determine dry-matter content. The yields are given in Table 2.

\section{Table 2. Yield of Forage from Demonstration Area}

\begin{tabular}{l|c|c}
\hline \multirow{2}{*}{ AREA } & \multicolumn{2}{|c}{ YIELD IN TONS PER ACRE } \\
\cline { 2 - 4 } & GREEN WEIGHT & DRY WEIGHT \\
\hline Treated & 5.98 & 1.27 \\
Untreated & 3.61 & .86 \\
\hline
\end{tabular}

The results, as indicated by both yield and appearance of the demonstration plots, show a pronounced increase from the application of the liquid manure. 
The analysis of the liquid manure used showed a much lower content of both nitrogen and potash than is normally recorded for urine. The average nitrogen content was only about 0.169 per cent $N$ and the average potash content only 0.225 per cent $\mathrm{K}_{2} \mathrm{O}$. The low content of both nitrogen and potash on November 9 (Table 1) was found to be the result of water from the downspout on the barn draining into the pit. However, even after this was corrected, the analyses continued to be low.

A calculation of the amount of liquid manure stored in relation to normal urine production during the various periods showed that from 50 to 83 per cent of normal urine production was being held in the bedding used.

The low nitrogen and potassium content of the liquid seems to require some explanation. Fresh samples of urine were secured from eight cows in the herd. The nitrogen content varied from 0.63 to 1.78 per cent $\mathrm{N}$ and the potash content from 0.65 to 2.05 per cent $\mathrm{K}_{2} \mathrm{O}$. Since this is within the average range it would appear that the urine as voidech was not abnormally low in either nitrogen or potassium. Additional fresh urine samples were added to sawdust to determine if the nutrients were absorbed to a greater extent than the water. The results did not show any change in per cent composition following contact with sawdust. Volatilization of nitrogen during the drainage and storage period is possible, but this could not explain the similar reduction in potassium, which is not volatile. The most logical explanation would seem to be dilution of the urine with the water normally present in the solicl feces. This would be expected to be low in water soluble nitrogen and potassium. There is also the possibility, not explored here, that there might be absorption of nitrogen and potassium by the solid excrement.

\section{Yields from Experimental Plots}

A series of 15 treatments with four replications (a total of 60 plots, each $12^{\prime} \times 30^{\prime}$ ) were laid out in randomized plots in the spring of 1952 in the forage area. Treatments included three rates of liquid manure to give 20,40 and 60 pounds of nitrogen per acre and three rates of 10-10-10 to give the same amounts of nitrogen. Yield records for three years (1952-1954) were obtained.

In 1952 the liquid manure was added on May 23 immediately after the first cutting. Yields of hay harvested on July 8 were $0.28,0.32,0.50$, and 0.51 tons per acre for the check, 20-, 40- and 60-pound rates of application of nitrogen in liquid manure respectively. Statistical analysis for all treatments showed that there were significant differences between treatments when all 15 treatments were considered. Inasmuch as the 
lowest yield in any treatment was 0.27 and the highest 0.56 , it may be reasonably concluded that liquid manure increased yields of forage.

Liquid manure was applied on June I after the first hay cutting in 1953. The 1953 season was very dry during midsummer, the June and July rainfall being 4.39 inches below normal. As a result, growth of forage was very slow and yields of second cutting made July 30 after a two-month growth period averaged only 0.42 tons per acre for all plots. Moisture was more limiting than nitrogen, and differences in yield were not related to any treatment.

In 1954 the liquid manure was applied April 19, about the time growth started. Yields on all plots were good, averaging 2.24 tons per acre, but there were no significant differences for any treatment.

Variability in the plots used for experimental work was large, the coefficient of variability ranging from 20.92 to 32.0 per cent. As a result normal expected differences from treatments were masked. Results from other tests with various nitrogen fertilizers as well as the demonstration plot yields would indicate a benefit from the nitrogen in liquid manure on areas where nitrogen is deficient for the crop being grown.

\section{Distribution Equipment}

It is not difficult to make a spreader to distribute liquid manure. For small-plot work or for farms with 10 to 15 animals, a spreader consisting of steel drums mounted on a 2-wheel trailer or the utility carrier of a tractor may be used (Figure 1). Two 55-gallon steel drums can be fastened together and mounted on a base, as shown in Figures 2, 3, and 4. Two-inch steel pipe, as shown in Figures 3 and 4 , connect to one discharge valve emptying into a V-type wooden trough for distribution. Holes one inch in diameter, drilled four inches on center, provide good distribution of the liquid. Only one of the barrels needs to have an opening at the top for filling. The liquid will flow through the twoinch pipe to the other. A small breather hole one inch in diameter should be drilled in the top to let the air escape as the tank fills and to allow air to enter as the tank empties. A single two-inch molasses valse rorks satislactorily for controlling the discharge into the spreader trough.

\section{LARGE DISTRIBUTION SPREADER}

1)airy herds of 50 or more animals require a larger spreader than the onc described above. A 500-gallon tank nuounted on a 4 -wheel farm wagon makes a satisfactory spreader (Figure 5). The trough at the rear of the tank, as shown in Figure 6, is essentially the same as the one on 


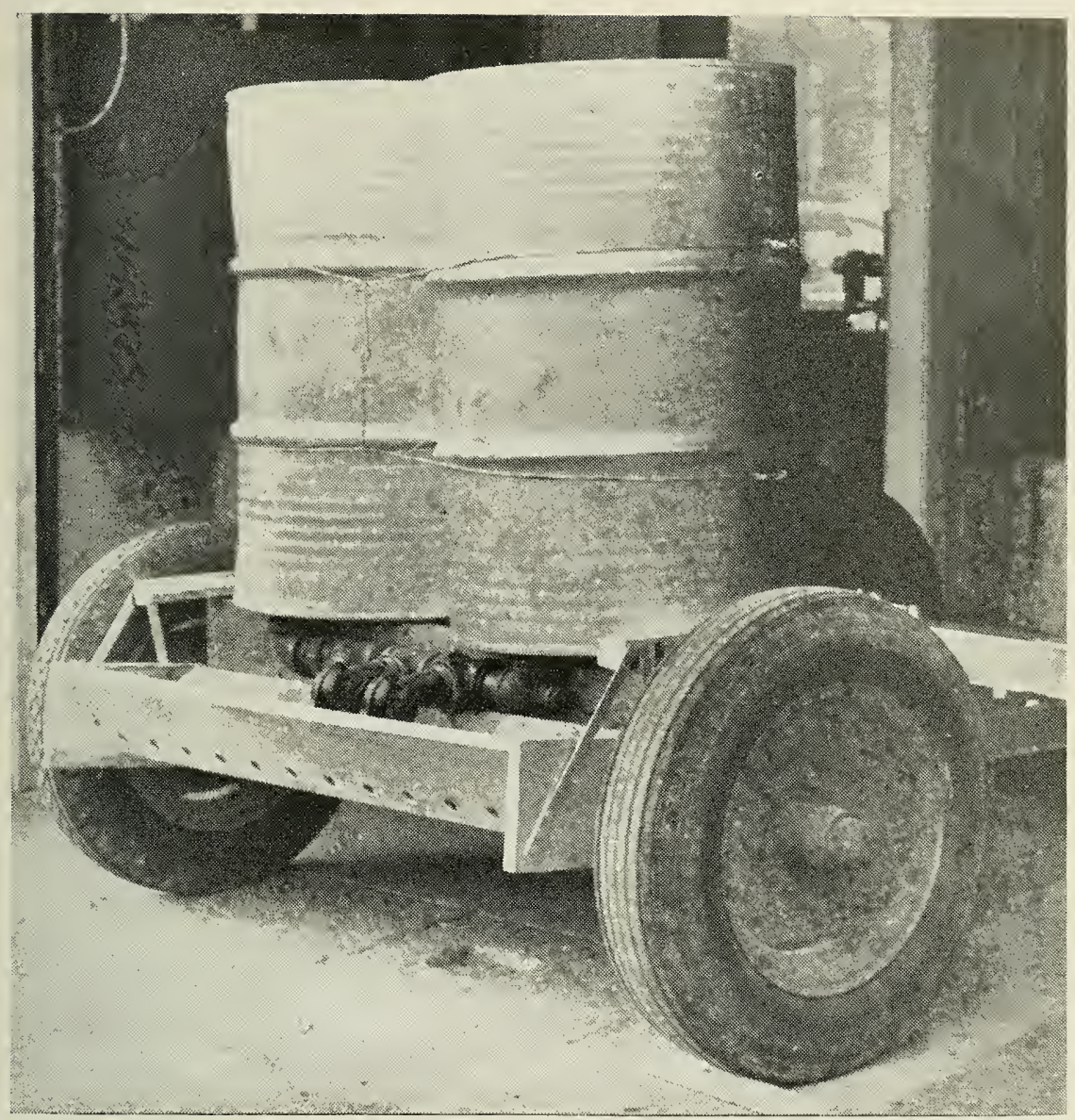

FIGURE 1. Two 2-inch molasses valves gave two rates of flow on test plots. Trough with 1 -inch holes, 4 inches on center, provides good distribution.

the small spreader except that it is longer. The unit shown is 6 feet wide. Two, two-inch molasses valves are used to control the flow of liquid from the tank to the trough. These valves are turned into two-inch pipe couplings welded to a steel plate, as shown in Figure 6, which is fastened to the end of the tank with lag screws. The lever mechanism, shown in Figure 6, couples the two valves together and permits the tractor operator to open and close the valves at will from the tractor seat. This is necessary when turning around at the end of the field or in case the tractor stalls or gets "hung up" in wet ground. Details of the valves, lever mechanism, and trough are shown in Figure 7 . 


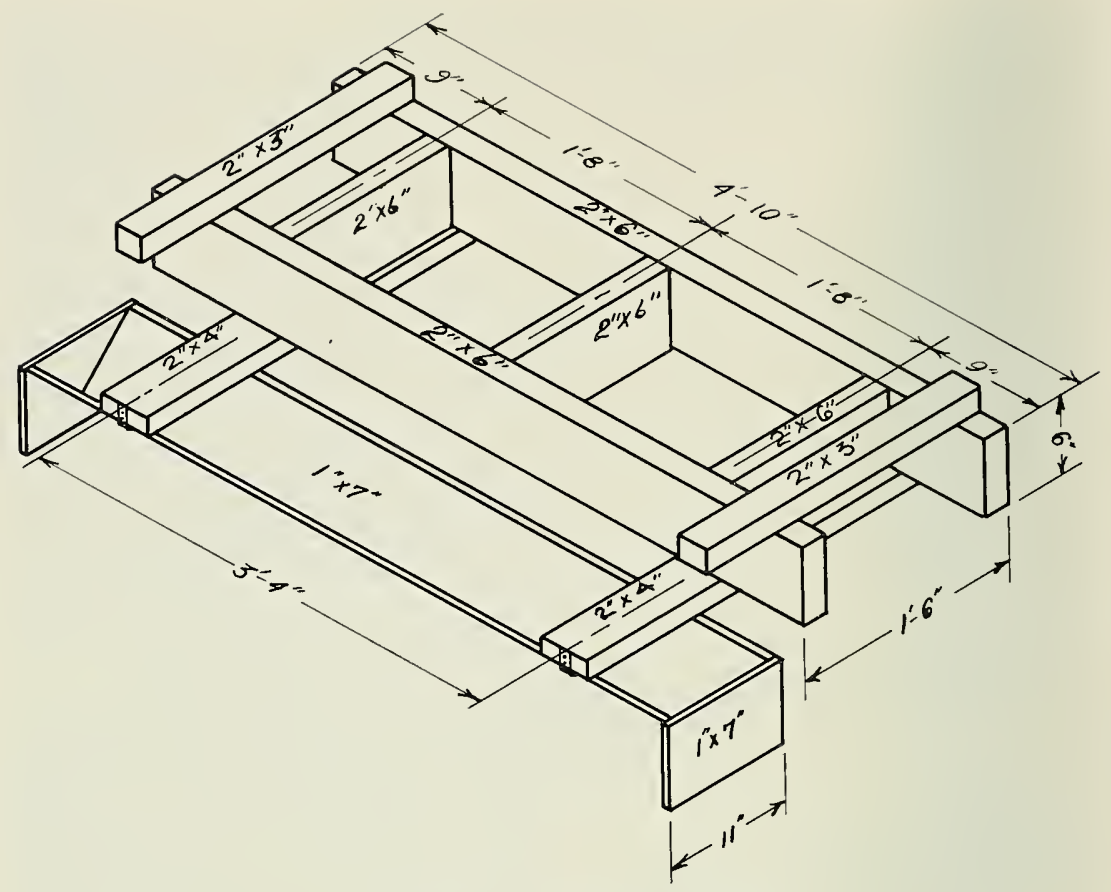

WOOD FRAMEWORK

FIGURE 2. Two by six-inch wood framing for base to support barrels and trough.

\section{COLLECTION AND STORAGE SYSTEM}

One, 2,000-gallon concrete reservoir placed below ground was ample for a 80-cow herd. Vitrified bell tile, as least four inches in inside diameter, was used to carry the liquids to the storage tank from the gutter in the dairy barn and from the drain in the bottom of the manure pit (Figure 8.)

\section{LIQUID MANURE PUMP}

A Parma* all-purpose, non-clogging manure and sewage pump, powered by a 3-horsepower electric motor, pumped the liquid manure from the storage tank (Figure 8) to the distribution equipment. The pump used in this project had a capacity of 300 to 400 gallons per minute so that the time spent loading was a little more than one minute.

* Manufactured by the Parma Water Lifter Company, Parma, Idaho. 


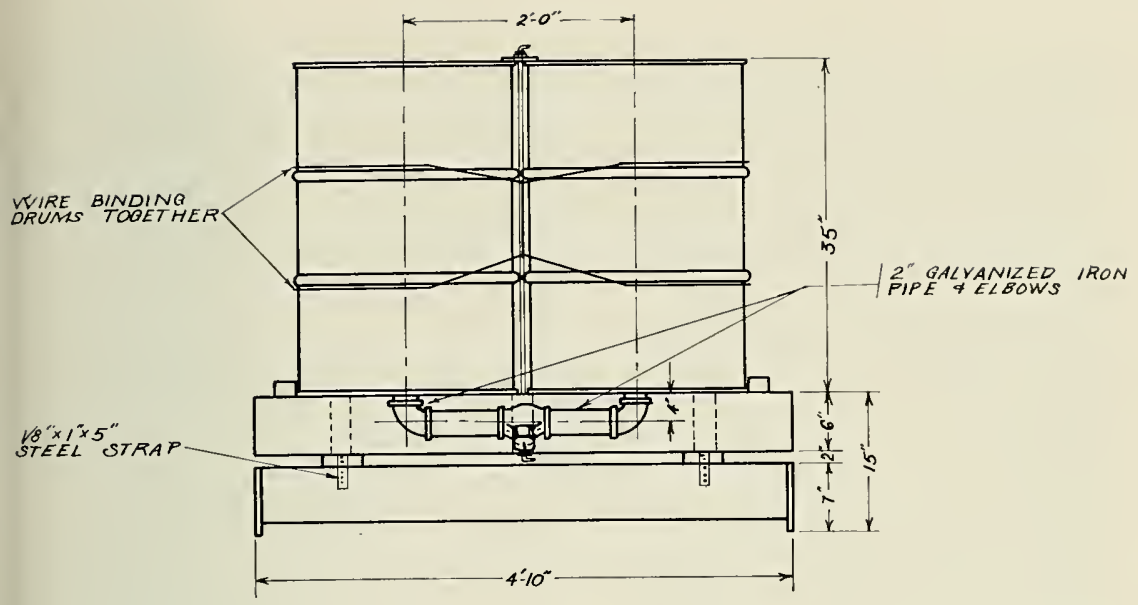

FRONT VIEW

FIGURE 3. Two, 50-gallon drums with 2-inch pipe fittings and molasses valve.

It should be remembered that pumps having smaller capacities are available. The terrain around many barns is such that the storage tanks could be placed in a location where gravity would move the liquid manure to distribution equipment without the use of a pump.

The equipment to store and distribute liquid manure is easy to construct, relatively inexpensive to build, and is especially adapted to farms on which a gravity system could be employed.

Note: Sce following pages for Figures 4, 5, 6, 7, and 8. 


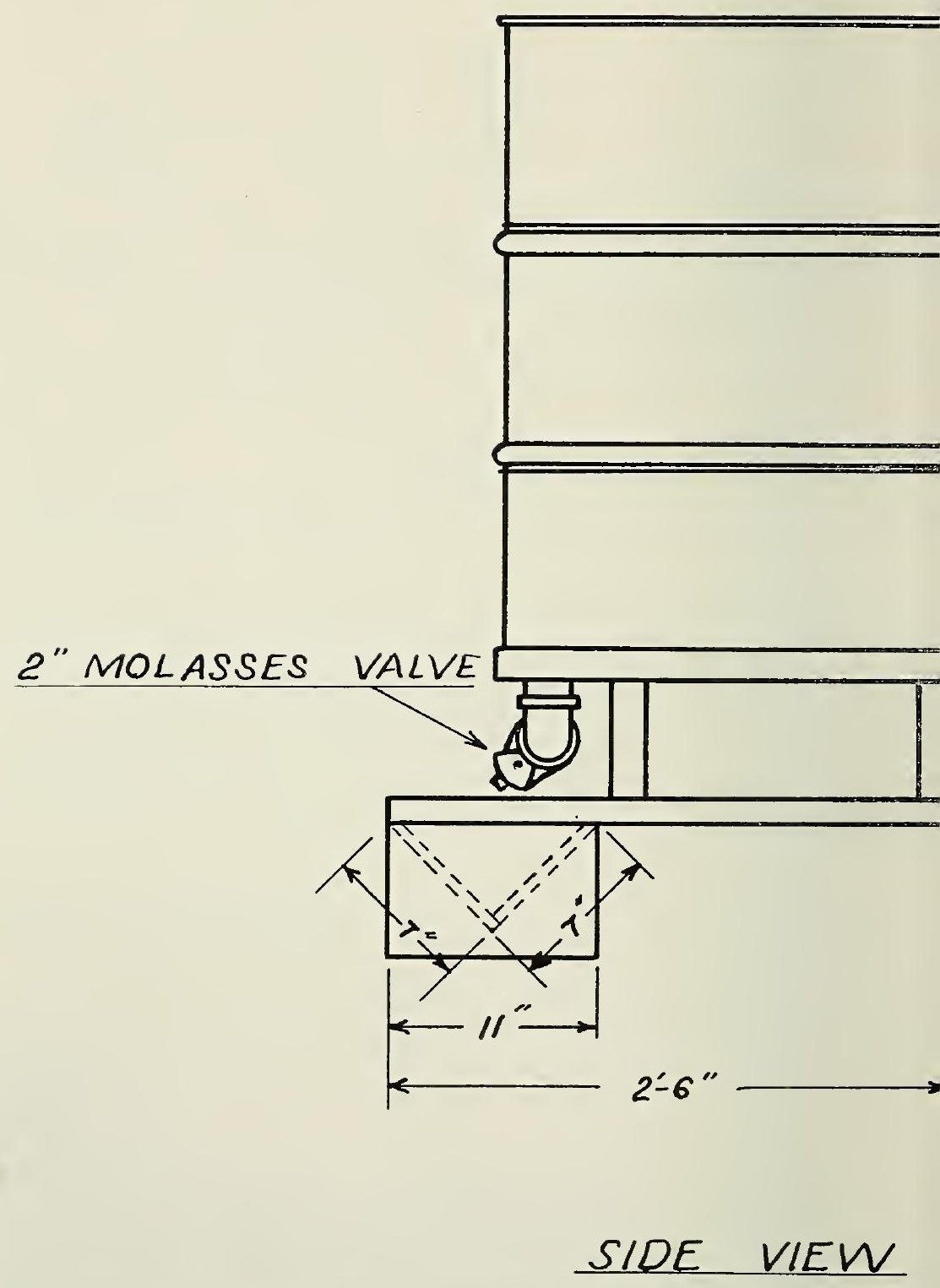

FIGURE 4. Side view of barrels, valve, and spreader trough. 


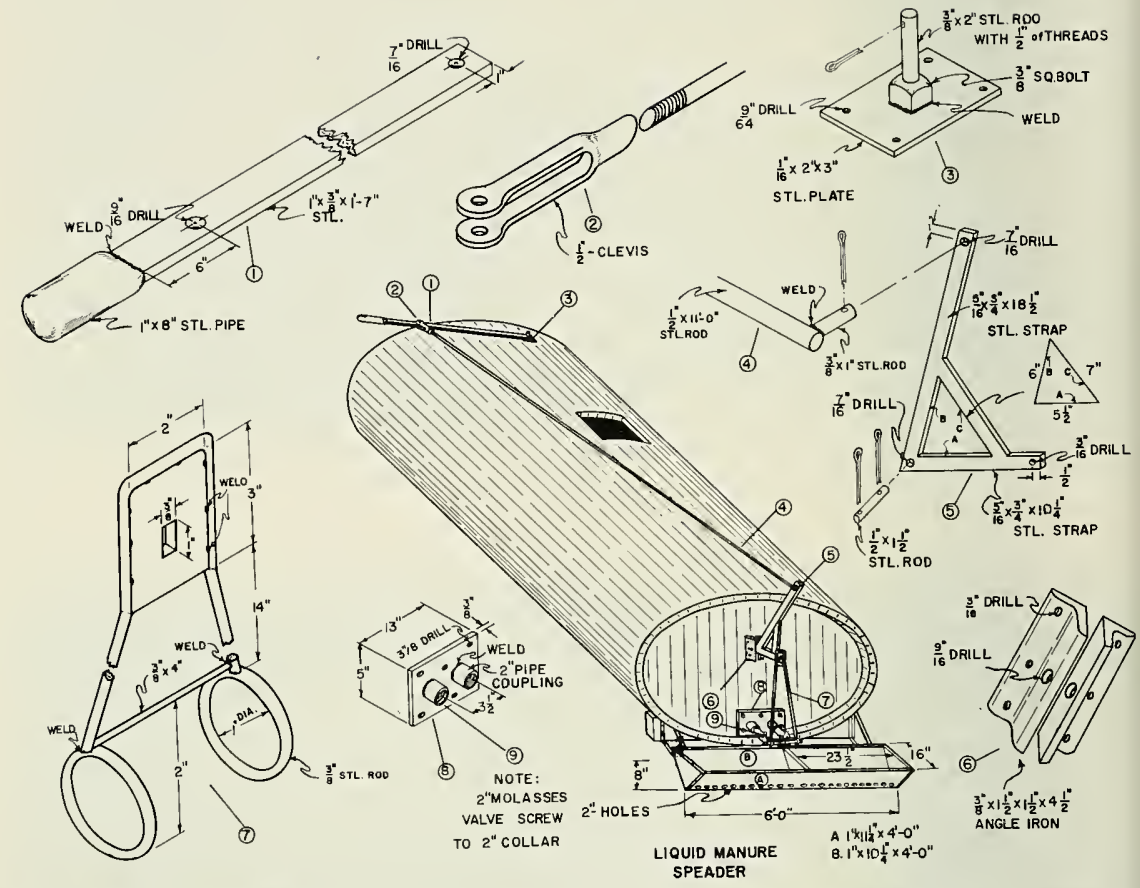

FIGURE 7. Details of control mechanism for valves and spreader on 500-gallon tank. 


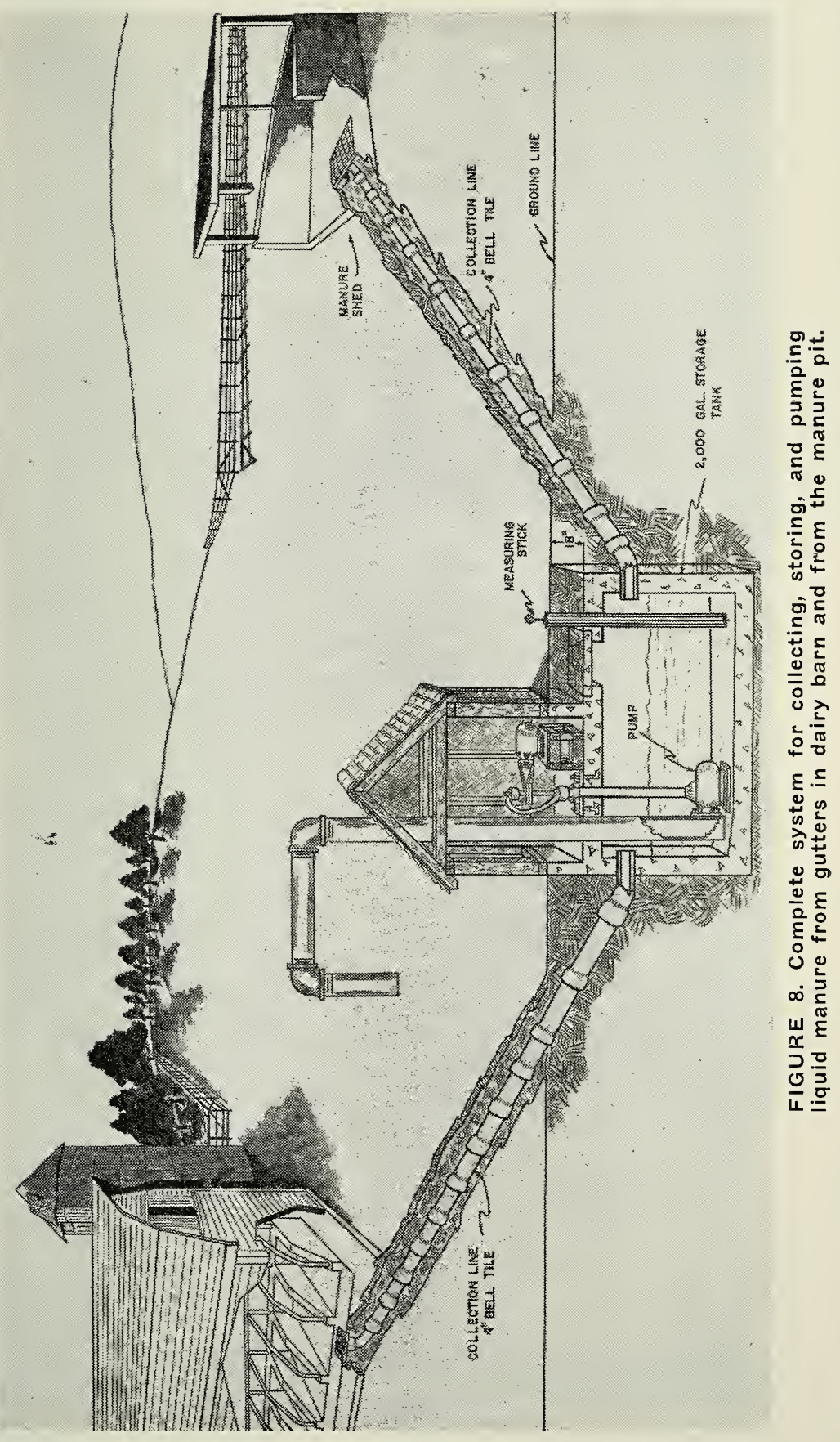


